American Journal of Economics and Business Administration 1 (2) 79-96, 2009

ISSN 1945-5488

(C) 2009 Science Publications

\title{
The Marginalization of Globally-Born Businesses: Ethnically Divided Trade in Hamburg and the World Economy-The Case of Global Persian Carpet Trade through Ethnic Networks
}

\author{
Shahamak Rezaei \\ Department of Society and Globalisation, Roskilde University, Denmark
}

\begin{abstract}
Problem statement: Persian carpets have long been a major commodity in the world market, controlled by the Tehran Carpet Bazaar and the Hamburg Free Harbor. Today about 200 private traders in the Hamburg Free Harbor area export their carpets to about 10,000 private carpet traders throughout the world, these being mainly of Iranian origin. The case of Persian Carpet represents one of the most magnificent and powerful examples of ethnic enclave economy in contemporary world. Approach: This study brought about some in depth knowledge, qualitative as well as quantitative, of how such an ethnic enclave economy of scale operates, how it reproduced itself and how it met the challenges, be it political, demographical or others. Results: The study showed, that in spite of major political turbulence in Iran since 1979, the spreading of state controlled trading companies inside and outside of Iran and increasing international market pressure due to the growth of copying production of Persian carpets in other countries, the Tehran-Hamburg axis remains the core of this trade-with private Iranian traders occupying the dominant position on both sides of the transaction line. Taking a closer look it became obvious that in particular, it is Iranian traders of Azarbaidjan descent who speak "Azari", a language similar to Turkish, who control the trade in both cities. Understanding the character and strategies of ethnic economy and ethnic enclave economy this study concludes, that it was necessary to look beyond and within the demarcation of national background and even ethnic boundaries in a broader sense according to which these phenomena mistakenly had been attempted to be explained. Conclusion: The engine of ethnic enclave economy cannot be upheld without a core, entrance into mainstream economy which required both more than common national and ethnic background. The challenge for this economy is how to dissolve from strong ties to more loose organization based on rationally structured mode of organization. So far, however, the limited group of traders stick together in order to remain in control of this world-wide billion dollars trade.
\end{abstract}

Key words: Globalization, global trade, world economy, ethnic entrepreneurship, business network, ethnic network, business clusters, ethnic enclave economy, ethnicity and "sub-ethnicity", business break-out, weak ties and strong ties, SME's and growth, socio-economic mobility

\section{INTRODUCTION}

The persistence of the Tehran-Hamburg axis, in spite of political and market turbulence, as well as ethnic segregation as the dominant organization characteristic of the Hamburg Free Harbor, stand out as milestones in the presented case. Historical evidence and statistical data is presented that supports these points.

The theoretical framework, established below, is partly a point of reference and partly the arena in which this study's contribution to theoretical articulation and more comprehensive conceptualization take place. The analysis of the case, based on quantitative and qualitative research methods, including desk studies and historical review (described below) will be set in perspective with the existing knowledge about the dynamics and mechanisms of ethnic economy and ethnic enclave economy.

\section{MATERIAL AND METHODS}

The methodology of the case, with regard to the qualitative parts, has been that of conducting interviews with 17 named interviewees and four who wished to remain anonymous (this sample representing more than $10 \%$ of the total population in question) amongst Persian carpet traders and their business network in Hamburg. The interviews conducted were partly explorative in nature and partly structured by way of an 
interview guide. Questions and answers were presented orally and notes were taken during the interviews. As a supplement to the qualitative data some quantitative statistical data were ordered from Eurostat via Statistics Denmark. To make a comparative investigation and examine the role of the Hamburg Free Harbor "Persian Carpet" traders vis-à-vis Iranian traders in other countries the same methodology was used in Denmark and four interviews in Denmark have been conducted. Three interviewees wished to remain anonymous. The qualitative part of the case has, finally, been supported by three additional face-to-face interviews conducted in the Netherlands, with one interviewee wishing to remain anonymous and three telephone interviews with former "Persian Carpet" traders in the Hamburg Free Harbor now residing in the USA: All three wished to participate anonymously. The names of non-anonymous interviewees can be found in "Acknowledgment" section.

\section{DISCUSSION}

Theoretical perspectives: The study of Persian carpet trade may add to theoretical debates in at least three fields: forms of globalization; concept of ethnic business and the shaping of business relations.

The immigrant business phenomenon, which is often labeled "ethnic business", has been studied intensively within the field of economic sociology, particularly in the $\mathrm{USA}^{[9,22,24]}$ but one also finds numerous studies which focus on the business and organizational side ${ }^{[1,2,13,15,23,25]}$. Moreover, the field clearly benefits from general economic and organizational theory on entrepreneurship, small-firm networks and institutional mechanisms in organizational life ${ }^{[5,18]}$.

Traditionally, ethnic businesses start as small family units, but over the years it is normal, that some spin-off of larger immigrant controlled companies. In some cases, however, particularly in East Asia, immigrant businesses also encompass numerous large firms which may even dominate economic sectors or entire national economies (cf. Reddings study of Chinese businesses in East Asian countries (1990)). And increasingly, the traditional illeducated and poor type of immigrant, is being substituted by the well-educated and wealthy immigrant, particularly in countries like Canada, the USA and Australia which are open to this type of immigration. This modern type of migration and immigrant business is more international in its orientation than the traditional type and often such immigrants operate businesses in more than one country ${ }^{[4,12,17,30]}$. These studies in various parts of the world suggest that both the old type of loose coupling of immigrant businesses across borders, as well as the modern and more systemic type of international integration of immigrant businesses, may be of relevance to our understanding of how immigrant businesses in one country are linked to similar business communities in neighboring countries as well as to immigrants' countries of origin.

Internationalization processes are usually understood as large firm driven, with large firms becoming international or global more quickly and more extensively than SMEs and with SMEs often being understood only as sub-suppliers to the large, international units and hence as reactive rather than proactive.

Although this conceptualization seems to capture the main current in the internationalization process, there are strong indications of a serious large-firm bias in this standard conceptualization. Small firms may group together horizontally in national or international networks to gain international competitive strength and a more proactive role in the restructuring process; or SMEs may be born international rather than sticking to the standard model of local/national growth preceding internationalization; or SMEs may be embedded in international social networks which link together even tiny business units at the international scene and sometimes result in surprising semi-standardization of certain types of businesses across borders. A substantial proportion of international business is still conducted by family firms organized along kinship lines ${ }^{[10]}$ and through trading diasporas. Trading diasporas share several features, such as strong ethnic identity and mutual dependence, informal networks based on mutual trust and family reputation and a belief in the utility of knowledge from all possible sources ${ }^{[11]}$. The formation of international business centers through trading diasporas around the world, such as London, New York, Hong Kong, Dubai and Hamburg has created supra-national suppliers of goods and services which through formal and informal business networks function as commercial and financial connection points between immigrant business communities and immigrants' countries of origin. The formation of immigrant business networks across countries can be understood as a "bottom-up" globalization process, which complements the standard large firm/top-down one.

A second theoretical prospective of relevance to this study concerns the concept of ethnicity. Broadly stated, ethnic groups are those groups that "entertain a subjective belief in their common descent because of similarities of physical type or of customs or both, or because of memories of colonization and migration" ${ }^{[26]}$. In principle, everyone is ethnic. Geertz suggests a more stringent definition of ethnic groups based on the primordial tie or the "longing not to belong to any other group" ${ }^{[7]}$. Between 
these broad and narrow definitions of "ethnic groups" one is proposed by Yinger, which is subscribed to here and defined as "a segment of a larger society whose members are thought, by themselves and/or others, to have a common origin and to share important segments of a common culture and who, in addition, participate in shared activities in which the common origin and culture are significant ingredients" ${ }^{, 28]}$. Ethnic business literature tends to define ethnic groups in terms of their foreign national origin and as Light suggests "Ethnic economies depend upon ethnicity not national origins for their boundaries and national origin is just a convenient indicator of ethnicity, not the real thing" "[16] The presented case here contributes to the understanding of what "Ethnic" means in ethnic businesses. Not only separate (sub) ethnic business networks, such as those found by Light in his study of Iranians in Los Angeles ${ }^{[14]}$, but also a hierarchy of (sub) ethnic groups from the same country and a pattern of overlapping ethnic identities. Besides the study adds a new perspective; that is another further move beyond boundaries of ethnicity and closer to the core cluster of individuals or controlling elite, the inner circle, entrance in which requires ethnic solidarity only as a minimum of conditions to be met. Even stronger ties will be required, as far as the inner circle (the insiders within the larger ethnic group) through historical struggles and strategies have established privileged positions.

A third theoretical topic of relevance for the study is that of business relationships within and across ethnic groups. Granovetter pointed in 1973 to the importance of "weak ties" while "ethnic business" literature suggests the importance of "strong ties" seeing the locational clustering of immigrant businesses as economic advantage $^{[16]}$. Taken together this literature suggests that immigrant businesses flourish in close-knit immigrant communities-"the network advantage"-and in economic sectors where they enjoy a competitive advantage due to their cultural insight and knowledge-"the cultural competence advantage". Usually, therefore, immigrant businesses are strong in city areas where many immigrants live and in sectors which deal with cultureloaded goods and services.

The issue of the immigrants' concentration in specific economic sectors where they enjoy a competitive advantage due to their cultural insight and knowledge"the cultural competence advantage" can also turn to become a disadvantage due to the fact of redundancy in business contacts "to the extent that they lead to the same people and so provide the same information benefits",[3]. Therefore concludes Burt ${ }^{[3]}$ in referring to Granovetter ${ }^{[8]}$ "information circulates at a high velocity within these clusters. Each person tends to know what the other people know. Therefore and this is the insight of the argument, the spread of information on new ideas and opportunities must come through the weak ties that connect people in separate clusters ... Hence the strength of weak ties. Weak ties are essential to the flow of information that integrates otherwise disconnected social clusters into a broader society".

\section{RESULTS}

Historical process of Persian carpet trade: (This part is mainly based on the interview with $\mathrm{Mr}$. H. Shayesteh in "Hamburg Free Harbor" and his four articles "Die Pioniere des Persischen Teppichhandels, (in English: The Pioneers of Persian Carpet Trade $)^{[20]}$ official publication of the Association of the Iranian Carpet Importers, Verband Iranischer Teppichimporteure (VIT)). To trace the history of the Persian carpet is to follow a path of cultural growth of one of the ancient civilizations. From being simply articles of need, as pure and simple floor entrance coverings to protect the nomadic tribesmen from the cold and damp, the increasing beauty of the carpets attracted new ownerskings and noblemen and those who looked for signs of wealth or adornment for their fine buildings.

Many people in Iran have invested their entire wealth in Persian carpets-often referred to as an Iranian stocks and shares-and there are underground storage areas in Tehran's Carpet Bazaar that are full of fine specimens, kept as investments by shrewd businessmen. And for many centuries, the Persian carpet has received international acknowledgement for its artistic splendor. Thus, today, Iran produces more carpets than all the other carpet making centers of the world put together. The element of luxury with which the Persian carpet is associated today is in marked contrast to its humble beginning among the nomadic tribes. Then, it was an article of necessity to protect the tribes from the bitterly cold winters of the country. But out of necessity was born art. In those early days the size of the carpet was often small, being dependent upon the size of the tents or room in which the people lived. Besides being an article of furnishing, the carpet was also a form of writing for the illiterate tribesmen, who wove into their carpets, illustrations of their fortunes and setbacks, their aspirations and joys. It also came to be used as a prayer mat by thousands of Muslim believers.

Thus began a process of people handing down their skills to their children. To make a carpet in those days required tremendous perseverance. Even when carpet making developed to the stage of workshops, with several employees working on the same carpet, it was a question of months and often years of work. A key feature in making the carpets was the bright colors used 
to form the intricate designs. The manufacture of dyes used involved well kept secrets handed down through the generations. Insects, plants, roots, barks and other substances found outside they were all used by the tribesmen.

Historical (This part is mainly based on "The Science and Art Foundation, by Professor Abbas Edalat, Imperial College, London, http://tehran.stanford.edu) records show that the court of Cyrus the Great (Cyrus the Great founded the Persian monarchy over 2,500 years ago), was bedecked with magnificent carpets. Classical tales recount how Alexander the Great found carpet of a very fine fabric in a Cyrus tomb. The next great period in the history of Persian carpets came during the Sassanian dynasty, from the third to the seventh century AD. By the sixth century Persian carpets had won international prestige and were being exported to distant lands. The climax came with the Safavid dynasty in the sixteenth century. When Shah Ismail occupied the throne in 1499 he began laying the foundation for what was to become a national industry that was the envy of surrounding countries. The most famous of the kings of this era, Shah Abbas, more than any one else transformed the industry, bringing it from the tents of the wandering nomads into the towns and cities. In Isfahan, which he made his capital, he established a royal carpet factory and hired artisans to prepare designs to be made by master craftsmen. He charged officers of the crown to ensure that the integrity of the industry was maintained and during his reign the art of carpet weaving/knotting once again achieved monumental acclaim. The best known carpets of the period, dated 1539, come from the mosque of Ardebil in Azarbaidjan province and, in the opinion of many experts, represents the summit of achievement in carpet design. The larger of the two is now kept in London's Victoria and Albert Museum while the other can be seen at the Los Angles County Museum. Shah Abbas also developed the use of gold and silver thread in carpet weaving, culminating in the great coronation carpet now held in the Rosenburg Castle, Copenhagen, which has a perfect velvet-like pile and gleaming gold background.

These carpets were, of course, made for the court and the great nobles and were protected as well as any gold treasure. Growing demand from the great royal courts of Europe for these gold and silver threaded carpets led to a great export industry. As the seventeenth century wore on there was an increasing demand for luxury and refinement. A set of silk carpets woven to surround the sarcophagus of Shah Abbas II achieved such a rare quality that many mistook them for velvet. But they were the last example of really high achievement in carpet making from that era in Persian history. Somehow, inspiration steadily began to diminish and, as the court became increasingly impoverished, the quality of the craftsmanship began to fall away. When Shah Abbas' capital city of Isfahan was sacked in 1722 a magnificent period in the history of not only carpet weaving but also of art itself came to an end. The great carpet weaving tradition fell back into the hands of wandering nomads who had maintained their centuries-old traditions and skills, that is apart from a few centers, principally, Josheghan, Kerman, Mashad and Azarbaidjan. Even the less prestigious/lower quality school rugs produced by the remaining centers were in danger of being ruined as an art form by the growing demand of the West in the mid nineteenth century for quantity at the expense of quality. Since the first decade of the twentieth century only a few foreign companies, especially the British OCM, known as the East London Company, had exclusive rights to trade in Persian carpets.

By the beginning of the twenty-first century the last Gajarieh monarch was dethroned and Reza Pahlavi came to the throne. Cheap dyes, low quality wool, chemical washing and even meaningless designs supplied by the European importers almost brought the industry to its knees. After sporadic and largely unsuccessful efforts to stop the rot, the government took drastic action and confiscated the carpets in which cheap dyes and low quality wool had been used. The dye masters soon came to their senses and there began a new era of revival for the carpet crafts.

The new monarchy took some steps toward nationalization of certain industries. One of the steps was establishing the "Iran Carpet Company" in 1935, firstly diminishing and then later abolishing, the role of foreign companies in the carpet trade, especially the British OCM company. It was at this point that the nationalization process began. Reza Pahlavis ideas led to the creation of a "State Monopoly" on the Persian carpet trade and gave sole trading rights to the "Iran Carpet Company". But soon after, following an initiative by a private trader from Tabriz (the Ghalichi family, described below as one of the "pioneers", headed the delegation), a meeting was set up in Tehran and Reza Pahlavi agreed to let private traders operate on equal terms with the "Iran Carpet Company"[21].

Text 1: The Pioneers of International Persian Carpet Trade: The Case of the Ghalichi Family: Evidence is based on the life story of Mr. Majid Ghalichi, who was born in 1926 and who became one of the Persian carpet traders in Hamburg Free Harbour. The story is also published $\mathrm{in}^{[21]}$ and according to the 
same source, is also documented in the Iranian Encyclopaedia by G. Mosaheb, Persian Carpet section.

Majid Ghalichi's maternal grand father, Yousef Ghalichi, is officially recognised as the first known/documented case of a Persian carpet exporter to Istanbul. In 1874 Yousef Ghalichi began his journey from Tabriz to Istanbul carrying four carpets on the back of a camel. Yousef Ghalichi returned home from the journey six months later and prepared another tripthis time with his cousin, Hadj Abdollah Ghalichi and his paternal grandfather, Majid Ghalichis. The journey took place in 1876-7 and Abollah's oldest son, Ali Akbar Ghalichi, (Majid Ghalichi's oldest uncle) also accompanied them on the second trip. The duration of the trip was about 3-4 months. Abdollah returned to Tabriz and this time Yousef travelled to Istanbul with Abollah's second son, Mirza Ali Asghar Ghalighi, who was 18 years old. Mirza Ali Asghar Ghalichi was the father of Majid Ghalichi. Yousef Ghalichi returned to Tabriz and supplied the two brothers with carpet from Tabriz to Istanbul. The two brothers and, later, a third one, changed their bases between Istanbul and Tabriz every second year. After two years stay in Istanbul, Mirza Ali Asghar Ghalichi (Majid Ghalichis father) returned to Tabriz and married Yousef Ghalichi's daughter (Majid Ghalichi's mother). Later on when they expanded the business, the Tabriz carpet production was insufficient to meet demand. Therefore, they expanded their business concept to collect carpets from different regions of Iran, gathering the carpets together in Tabriz Carpet Bazaar and then sending the carpets on to Istanbul.

From Istanbul the carpets were despatched to different European destinations. Ghalichi's family business expanded and became well known and European traders travelled led to visit the family's "Trade House". On one occasion, one of the European customers invited the family to participate in the "First International Fair of Vienna" in 1892. The Ghalichi family, as the only Persian Carpet traders, participated in the fair with huge success. This led to the beginning of collecting a huge number of carpets from different parts of Iran, resulting in a sizeable carpet demand in Iran. Soon after, some other Persian traders, mainly from Azarbaidjan province, started the same business in Istanbul. They were all gathered in the same area in Istanbul, "Valedeh Khan Saray". The most well-known pioneer families in Istanbul were: (1) Karbasi, (2) Dilmaghani, (3) Ahranjani, (4) Aerabi, (5) Sadaghiani, (6) Shalchi and (7) Reza Shahla. During WW I, the "Valedeh Khan Saray", was known as the Iranian "Saray", (Saray in Turkish means a kind of Bazaar). In the "Saray" all Iranian traders were situated in two- storey buildings and had office and warehouse space on the ground floor, while living on the first floor. Majid Ghalichi quoted his father, Mirza Ali Asgar, as saying "the funny thing was that our (the traders in the "Saray") kitchen chefs were all coming from Khoi, the first one of them came to Istanbul then suddenly they brought their family and friends to Istanbul and worked for us ${ }^{[21]}$, (Khoi is a small town in Azarbaidjan approximatley 80 km North West of Tabriz and very close to the Turkish border). After WW I some traders went back to Iran and worked in Tabriz, mainly due to the insecurity in Istanbul. Some other traders from Azarbaidjan, mainly Tabriz, were active in Tehran Carpet Bazaar, due to the geographical position of Tehran, it being located almost in the middle of the country. Another group of traders tried to make their base in other countries. That resulted in some of the traders settling down in London and making new bases. Majid Ghalichi's father and many others, however, decided to stay in Istanbul until 1939 when WWII began.

Taking the new situation into consideration and the condition of the buildings in the "Saray" the remaining Iranian traders were reconsidering their situation. All buildings in the "Saray" were built of wood and many places in Istanbul were subject to fire attacks and burned down. The possibility of Turkey's participation in the war worried traders. Majid Ghalichi's father, Mirza Ali Asgher Ghalichi and all the other remaining Iranian traders started to ship out their assets from Turkey to different destinations. Majid Ghalichi said that his father, Mirza Ali Asgher Ghalichi and all the other remaining traders, left Istanbul the same day as Hitler's troops entered Paris, namely, June 14th $1940^{[21]}$. This was the end of the Iranian Carpet traders' history in Istanbul at the "Saray" where, according to Majid Ghalichi, the ruins of the "Saray" can still be seen in Istanbul. The Ghalichi family returned back to Iran, while other traders started a new Persian carpet trade centre in London. According to Majid Ghalichi, after WWII, due to particular economic opportunities, Iranian Persian carpet traders moved from London and tried to build up a new centre in Hamburg. Majid Ghalichi decided to stay in Iran until 1962 and then moved to Hamburg and settled down in Hamburg Free Harbour $^{[21]}$.

Majid Ghalichi mentioned that his father, Mirza Ali Asghar Ghalichi, appointed one of their relatives, Mr. Javad Lavari, in around 1904, to work as the Ghalichi family's "purchasing agent" in Arak province, being located in central Iran approximately 150 miles south of Tehran and approximately 1000 miles south east of Tabriz, to purchase "Sarough carpets" (Sarough carpets are knotted in Arak province and are known to 
be of the finest quality) and then send the carpets to Tabriz. Finally, due to the long transportation time of round four to five months, the family decided to gather the carpets in Arak and ship them from the Persian Gulf to the $\mathrm{USA}^{[21]}$. This was the beginning of the new strategy, where traders not only sent their purchasing agents around Iran to collect different kinds of carpets with the aim of sending them back to Tabriz Carpet Bazaar, but they also decided to set up other trading centres across Iran. The consequence was the establishment of a concentration of carpet traders, mainly from Azarbaidjan, in the heart of the capital city's Bazaar, Tehran Carpets Bazaar.

The "Iran Carpet Company" is, today, the biggest producer of Persian carpets employing approximately 20,000 weavers and knotters located variously across 580 Iranian villages and 96 Iranian towns and cities, supported by 40 regional offices. Today, the activities of the "Iran Carpet Company" is divided into 2 divisions:

- Production and Trade 2. Support and Advisory services $^{[21]}$

Before WW I the Iranian "Persian Carpet" traders (the pioneers) were based in Istanbul and they exported from there to Europe. Evidence indicates that it was in 1874 when the first known case was recorded of a first private Persian carpet trader. He was named Hadj Yousef Ghalichi ("Ghali" is one of the ways to say "Carpet" in Persian) and he came from Tabriz, the capital of Iranian Azarbaidjan province (Evidence is presented in Text 1). The evidence also indicates that by increasing foreign demand for the Persian carpets, pioneers from Tabriz area could not meet the demand by only supplying Persian carpets from the Azarbaidjan area, mainly from Tabriz Carpet Bazaar. Pioneers tried to recruit purchasing agents in different parts of Iran. The purchasing agent's task at the beginning was to purchase, collect and gather carpets together and send them to Tabriz Carpet Bazaar. Soon after, however, they began to locate their agents in different parts of Iran and establish a few more centers across the country. The main gathering centre was, for geographical and political reasons, placed in the middle of the country, i.e. the Capital city, thus making Tehran the biggest new centre of trade. This was the beginning of the gradually increasing concentration of "Azari", "Persian Carpet" traders in the Tehran Carpet Bazaar (Evidence is presented in the last section of Text 1). Establishing international customer contacts via Istanbul and the setting up of a trade centre in the capital city of Iran almost in the middle of the country, made the traders less dependent on Istanbul. Due to defeat of the Ottoman empire which created insecurity in the country, the pioneers decided to move to London, by then the world's biggest trading centre including the "carpet trade" while some others moved to Tehran ${ }^{[6]}$. The Tabriz-Istanbul axis 1874-1930s was now replaced by a Tehran-Istanbul-London axis and later, in 1940, changed again to the Tehran-London axis. This lasted until 1945, when the Tehran-Hamburg axis replaced all former organizational arrangements and still is in force.

Figure 1 shows the developments in the international Persian carpet trade as well as illustrating the Ghalichi family's affinity relationships based on the patrilineal system that forms alliances of kinship, based on Text 1.

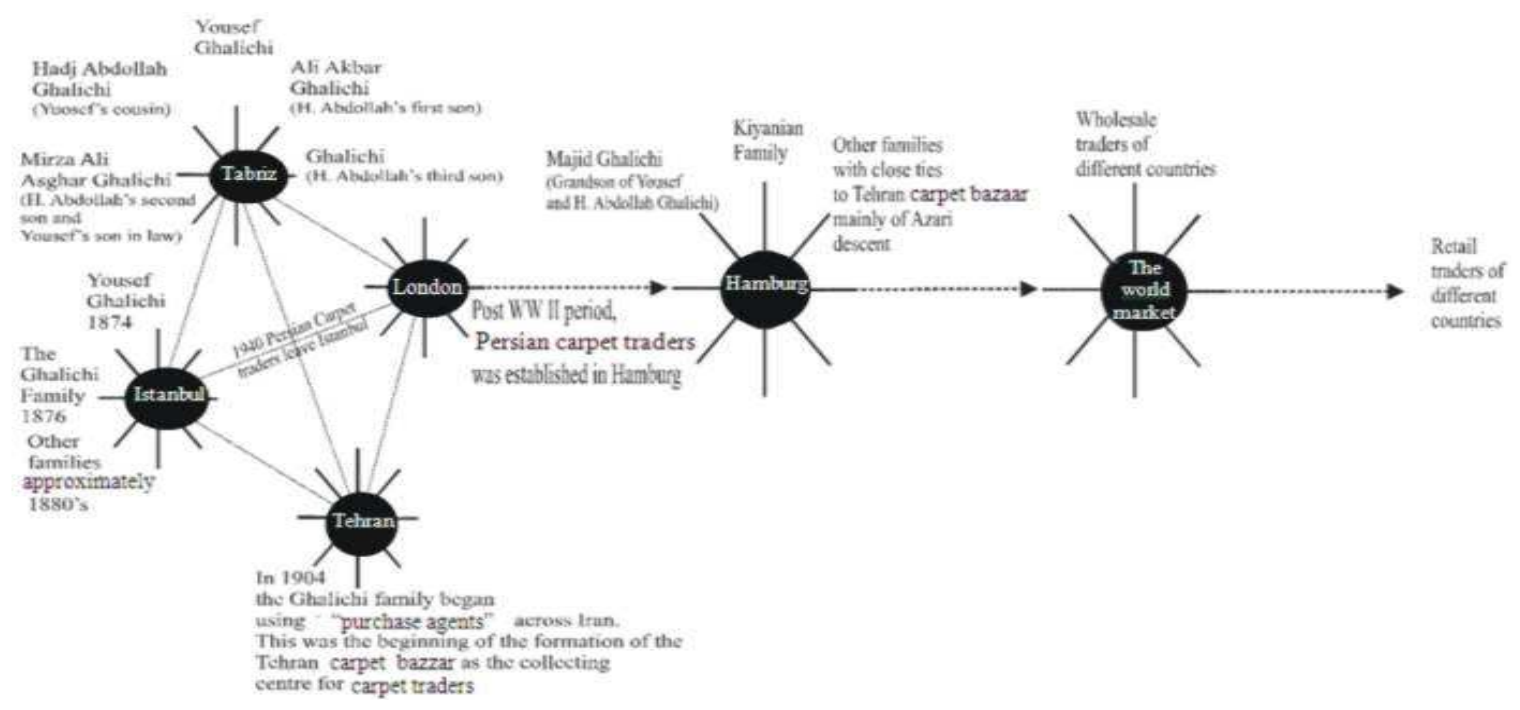

Fig. 1: The pioneers of the international Persian carpet trade 
Contemporary trade pattern for Persian carpets: The existing trade chain model is still, to a high degree, inspired by the model used by the "Pioneers" in the late 1800 s and early 1900s. There is a vast number of individuals and/or associations of producers located at the starting point in the trade chain, with each one producing different kinds of hand-knotted carpets in more than 30,000 different villages across Iran (According to interviews) ${ }^{[21]}$. Producers start their production either on receipt of an order that is issued by "purchasing agents" and/or "wholesalers" located in the provinces and/or on the basis of orders received directly from Tehran Carpet Bazaar. Depending on whether the finished product is ordered for the domestic or export markets the product will usually be sold on to a number of different "wholesalers" in Iran. Individuals (i.e., private traders) and/or associations of exporters who, due to historical and infrastructure factors operate mainly from Tehran and specifically from Tehran Carpet Bazaar (Due to limited space in Tehran Bazaar, in recent years many traders have chosen to locate only their offices within the Bazaar area, preferring to site their warehouses elsewhere in the city), order the carpets for the export market which are then transported to their counterpart overseas' contacts.

Individuals and/or associations of exporters can have several different counterparts located abroad and, depending on the level of "trust" and historical "trading records", they will be treated in different ways: for instance, concerning cash payments or the conditions attached to credit facilities and after sales service. The most common arrangement for foreign trade is for individuals and/or associations of exporters of Tehran Carpet Bazaar to draw up a co-operation agreement with individuals and/or associations of importers in the Hamburg Free Harbor. This kind of co-operation between the traders in Tehran and Hamburg is either based on kinship ties, which is the most common type, or through setting up joint-venture co-operations. Either way, two core elements common to both kinds of cooperations are "trust" and "historical trading records".

The exported carpets are usually purchased by individuals and/or associations of wholesalers in Hamburg Free Harbor. Here again, due to method of payment and/or credit and after sales service conditions, a key factor is mutual "trust" and "historical trading records". From here, individuals-and/or associations of world-wide wholesalers transfer the purchased carpets to their respective destination countries and forward the carpets to individual customers and/or retailers. Here once again, due to the relatively high sales value and the expectation that hand-knotted carpets have a very long life, requiring long-standing after sales service agreements, "mutual trust" and "historical trading records" are key factors in the transaction.

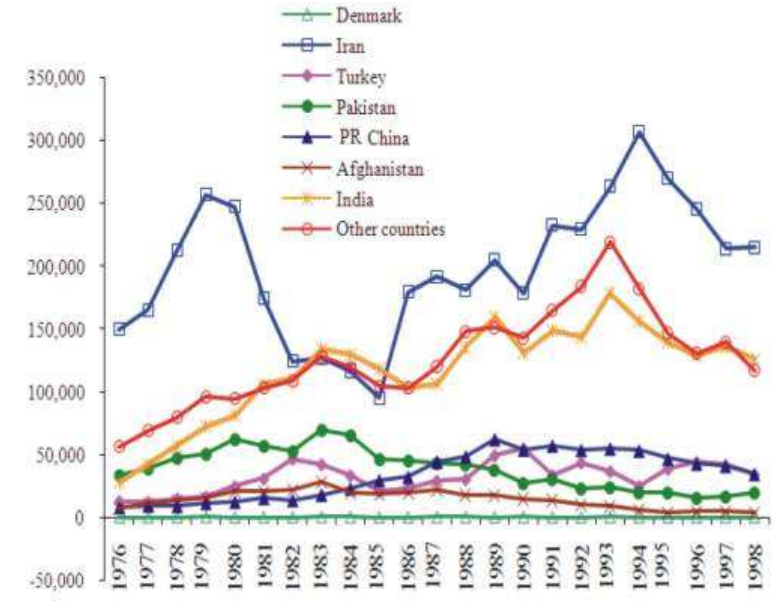

Fig. 2: Germans import of hand-knotted carpets from selected countries during 1976-1988 in ECU, Source: Eurostat/statics Denmark, Own calculations

The "newcomers" of importance have, since the Iranian revolution in 1979, been drawn from different groups consisting of both "private" and/or "governmental" bodies. The traditional trade channels have, as described later, survived many turbulent events and the traditional traders have been able to limit the development and expansion of "direct trade" channels. But the huge influx of new Iranian immigrant groups across the world, especially into Europe since the early 1980s, has created a new challenge to the "traditional Persian carpet" traders, mainly those in Hamburg Free Harbor, in such a way that formerly weak "direct trade lines" are becoming greatly strengthened, representing a serious business threat to "traditional" traders. (This discussion is subjected to more thorough analyses in part 5 and 6).

Figure 2 shows German carpet imports from selected countries during 1976-98. Figure 2 is based on Eurostat trade statistics obtained by special request through Statistics Denmark. (The Statistical data is based on product code number 5801 for the period of 1976-1987 and product code number 5701 for the period of 1988-1998. The change in product code numbers is due to official changes made by Eurostat and in both cases the codes cover "CARPETS OF TEXTILE MATERIALS, KNOTTED". The data source is Eurostat, EEC Special Trade, Comext2 k0282845, extracted by Statistics Denmark on March $21^{\text {st }} 2000$. As part of the same data extraction exercise product code numbers 5802 and 5702 covering "Kelims and woven carpets", were also purchased from Statistics Denmark. These latter product code 
categories are excluded mainly due to their low significance level when looking at the value per ton they represent in the international carpet trade compared to knotted carpets and also due to the nature of business being carried out by traders in Hamburg, namely, trade in "Knotted" rather than "Woven" carpets) The data is based on trade to and from Germany due to the fact that it was not possible to request data relating specifically to Hamburg. However, according to interview data there are only a few carpet traders in Germany (outside of Hamburg) that import carpets directly from carpet producing countries. That is, according to interview data, due to close ties between Hamburg Free Harbor traders and other carpet retailers across Germany as well as because of the relatively low prices in Hamburg Free Harbor compared with prices in the various carpet producing countries, better after sales service and accessibility is provided by traders in Hamburg Free Harbor. Statistical data for the period from 1976 until German reunification, covering the German Democratic Republic, were so insignificant that they could without any hesitation be combined with data for the Federal Republic of Germany and presented as one single data set.

Figure 2 shows trade data for the five largest handknotted carpet producing countries of the world and Denmark (it is important to note that only a handful of "other countries" have a sizeable production of handknotted carpets in the world). Denmark is included in the Fig. 2 in order to illustrate the Danish-German carpet trade axis. Figure 2 illustrates an overall dominance of carpets imported to Germany from Iran. The dramatic fluctuations in the Iranian data can be explained by certain historical events. The most remarkable fall in imports from Iran began in 1979 when the revolution in Iran resulted in an export ban on many different Iranian valuable products including Persian carpets. The combination of the export ban due to the revolution and the Iran-Iraq war and logistical obstacles, led to a weakening of Iran as the leading carpet exporting country to Germany. Export bans led to the establishment of a temporary Persian carpet trading centre in Dubai which, as discussed later, was mainly supplied by business men who smuggled carpets across the Persian Gulf. But the Dubai adventure did not last more than a few years and traders in Germany, Hamburg, won the position lost in a way that almost all carpet trading activities in Dubai were closed down. During the years of restrictions and supply shortages of Persian carpets, the other main carpet producing countries have experienced golden years, especially India. Also, according to the interview data, Indian producers are accused of copying Persian carpet designs and patterns and this is attributed as the most important reason for their success.

The curve "Other countries" represents both handknotted carpet producing countries other than those mentioned in Fig. 2, as well as all other countries with hand-knotted carpet exports to Germany. However it is mainly other European countries, which have significant exports of hand-knotted carpets to Germany. The curve shows that during the entire period of 19761998, there have been exports of hand-knotted carpets from "Other countries" to Germany and this is mainly due to the reason that Hamburg has been known as the centre of the carpet trade, both for carpet producing and non-carpet producing countries.

Another dramatic fall in Iranian exports began in 1994. One major reason here is the entrance of new players in the field. Due to certain "barter trade" agreements between the Iranian governmental and/or semi-governmental trading companies, foreign exporters to Iran operating from different countries agreed to receive a percentage of payments due to them in the form of Iranian non-oil products. One of these products was Persian carpets. One of the consequences was a drop in the trade with Hamburg. But since the new players had no knowledge about, or working relationships with the retail traders' network nor the required competency in the carpet trade, they just tried to get rid of the carpets at any price in order to minimize the losses they encountered. With an end result of failure, different countries exporting to Iran did not repeat this kind of trade. The situation described can also be detected by looking at the curve for "Other countries" in Fig. 3. As shown below the curve more or less follows the same tendencies as the curve for Iran. The curve "Other countries" shows a high export level of hand-knotted carpets to Germany and a sudden drop in 1993. This reflects the huge glut of hand-knotted carpets received by European countries from Iran as the "barter trade" part of trading agreements and the inability of these countries to sell them in their own home markets, consequently being forced to sell them at almost "give-away" prices to traders in Hamburg. Many of those interviewed amongst the Persian carpet traders of Hamburg Free Harbor did confirm purchasing Persian carpets from many European companies at reasonable prices, but they also criticized European companies for damaging the market by dumping stock on the Persian carpet market and for offering the carpets at below normal purchasing prices to the retail market-even selling the carpets at "Discount Shopping Malls". The over supply of hand-knotted carpets from "Other countries" of mainly Persian origin finally resulted in the reduction of German imports of hand-knotted carpets from Iran in 1994. 


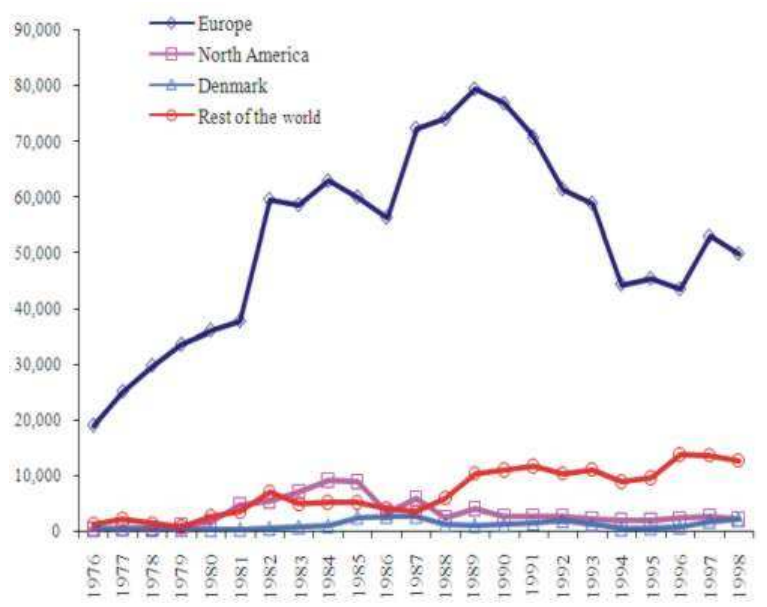

Fig. 3: German exports of hand-knotted carpets to selected regions and Denmark during 1976-1998 in 1000 ECU Source: Eurostat/statistics Denmark, Own Calculations

But due to falling prices and low demand the operation of these new players came to an end by the mid '90s. Germany's volume of imports from Afghanistan, PRC and Pakistan seem to be more or less stable throughout this period. German carpet imports from India seem to follow the trajectory of Persian carpets and that is mainly because India uses, to an extensive degree, the same patterns and design as those used in Persian carpets.

German imports of hand-knotted carpets from Denmark can be explained by the close ties that exist between the carpet traders of Denmark and Hamburg. A steady, although weak, export trend from Denmark to Germany, can be seen in Fig. 2, throughout the period 1976-1998. According to interview data, German imports from Denmark are due to two reasons. One is the concession agreements between the traders of Hamburg and Denmark. These give Danish traders, unable to sell the carpets, the option of re-exporting them to Germany as long as alternative customers exist in Hamburg. The other main reason relates to special carpets, mainly antique carpets or other rare kinds of hand-knotted carpets, where the possibility of achieving better prices is much higher in Hamburg for this special category.

Figure 3 shows the German (Hamburg) exports of hand-knotted carpets to different parts of the world. The Fig. 3 shows an increasing share of German exports to other European countries until the late 1980s as well as some decreasing tendencies since the beginning of the 1990s. This is mainly due to two reasons, (both of which will be discussed more thoroughly in parts 5 and 6 ). Firstly, there was a huge influx of new Iranian immigrants to European countries who, after settling down in the recipient countries, tried to import handknotted carpets from Iran. Secondly, a number of multi and/or bilateral barter trade agreements were drawn up between Iran and European countries also including some Iranian governmental and/or semi-governmental trade offices across Europe. As a solution to this situation the hand-knotted carpet traders of Hamburg tried to find alternative markets. This is illustrated by the increase in German hand-knotted carpet exports to "Other countries" from the late 1980s. The fall in exports to "North America" (this category includes the USA, Canada and Mexico) in the mid 1980s is due to import bans imposed by the USA on Iranian products.

The location of Persian carpet traders in Tehran and Hamburg Free Harbor and patterns of Ethnic segregation: The Tehran-Hamburg axis like the former ones, (Tabriz-Istanbul, Tabriz-Istanbul-Tehran and Tabriz-Tehran-London) is strongly concentrated, both in geographic and ethnic terms.

Looking closely at the Tehran Carpet Bazaar, evidence shows a strong dominance of Iranians from the Azarbaidjan province, mainly from Tabriz. Tehran Carpet Bazaar location a tight geographic concentration consisting of a few adjacent streets. Both domestic and export carpets are to be found here, but usually in different trading houses depending on the main nature of business line of the owner and the owner's international linkage relationships. Almost all carpet traders in Hamburg Free Harbor are represented by a counterpart in Tehran Carpet Bazaar and the existence of a "dual loyalty" relationship is clearly evident. The most common indication of this dual loyalty is the Hamburg trader's business card which contains two addresses: one in Tehran and one in Hamburg.

In Hamburg Free Harbor one finds marked ethnic divisions among the carpet traders, revealed in location patterns and the architecture of buildings. In order to understand these patterns, one needs to look closely into the history of the harbor.

According to an interview with Mr. Hamid Shayesteh, the Kianiyan family is one of the oldest Iranian trading families in Germany. The family's trading records are also documented and published by "Farsh Iran" ${ }^{[6]}$ being based on an exclusive interview with Mr. Hossein Kiyanian whose father established the Kiyanian Carpet Trading House in 1928 in Hamburg. At that time, Iranians were not able to trade freely in Germany and they were forced by some special regulations to trade via a third country trader. Those 
few Iranians residing in Germany chose Russia as their trading partner, so the "... normal way of trading at that time was to sell Iranian merchandize to Russia who sold it in Germany and the Iranians in Germany bought their German products from Russian businessmen in Germany and then sent them off to Iran",[6].

In 1929, on behalf of the Iranian Government, the Iranian ambassador to Berlin, Mr. Farzin, signed the trade treaty between Iran and Germany. The treaty allowed for both countries to open up for mutual trade purposes and permitted bilateral export and import quotas with the introduction of special quotas on dry fruits and carpets. According to the quotas, Iranians were allowed to export carpets up to a limit of approximately DM 8 millions per year. The treaty was in force both before and during WWII with some parts of the treaty still in force today ${ }^{[6]}$.

At the end of the WWII with the division of Germany into French, American, British and Soviet zones. The foreign troops introduced "Personal Ausweis", Personal Identification Documents, applicable both to Germans and immigrants residing in Germany.

Hossein Kiyanian, who has lived in Hamburg since 1936 and who was at that time 14 years old, explains that he left Hamburg for Iran during WWII. Shortly after WWII they returned to Hamburg and realized that the Kiyanian Carpet Trade House and their residence was totally destroyed due to bombing. H. Kiyanian describes the period of 1945-1949 as tough economic years. "The British authorities in Hamburg only issued a six-weeks permission of stay in Hamburg to us, so in 1947 we tried to set a base up in Paris to start our business and start a sojourner business life between Hamburg and Paris, until the situation improved in 1948 and the "First International Fair" was held in Hannover consisting of 4 tent-halls and that was the beginning of better economic conditions",[6].

The "Economic Reform" of Germany began in 1949 with Professor Erhard in the lead with his belief in "free-trade" which led to changes in the import quota system with Iran that had been introduced in the 1929 German-Iranian treaty. Later on in 1950 the quotas trade system between Iran and Germany was abolished ${ }^{[6]}$. An increasing number of Iranian "Persian Carpet" traders established their businesses in Hamburg which had the consequence of undermining the role of London as the world's leading centre for the "Persian Carpet" trade in favor of Hamburg.

According to the interview with $\mathrm{H}$. Shayesteh and documentation produced by $H$. Shayesteh and published by "Farsh Iran"[6], the number of named Iranian Persian carpet traders in Hamburg Free Harbor before 1960 was 59. According to H. Shayesteh, the majority of these 59 traders were either "Azari", descending from Iranian Azarbaidjan, or Iranian Jewish. According to interviews with more than 20 of the Iranian "Persian Carpet" traders in Hamburg Free Harbour and an interview with Mr. Heinz Oberlach, HHLA press officer and Mr. Nikandish, manager of V.I.T. "Verband Iranischer Teppichimporteure, the number of traders increased during the 1960s and 1970s from around 60-70 traders to around 100-120. In the period following the Iranian revolution in 1979 until the present day, the number of traders has increased to around 200-230, whom mostly are Azari.

According to the interview with Mr. Rainer Albrecht, Rainer Albrecht, Die Ausländerbeauftragte, (Referent für Ausländerrecht, an den Senat, Hamburg) special legal advisor in immigration issues for the "Senate of Hamburg", the official name of the city of Hamburg is: "Freie und Hansestadt Hamburg" (Free and Trade City Hamburg) and, in fact, Hamburg has had this status for several centuries. This might be one of the reasons why Iranian traders chose Hamburg as the place to establish their businesses.

The city of Hamburg has, due to its strategic position along the rivers of "Alster" and "Elb", suffered from several damaging attacks and wars. The creation of Hamburg actually started with a battle when, in the year 804, "Karl the Great" attacked from the eastern part of the "Alster" river and then started to build the old city of Hamburg. In 845 when the Vikings ruined the city, almost noone was left in Hamburg except for a few fishermen, traders and blacksmiths ${ }^{[6]}$. In 1188 the new city was built along the "Alster" river and harbor and shipping facilities were established. This marked the beginning of a wealthy and promising future for the city. The promising harbor business opportunities made it possible for Hamburg to declare itself as economically independent in the fifteenth century. It is since that time that Hamburg became known as "Freie und Hansestadt Hamburg"[6]. Another highlight in the history of Hamburg's harbor can be traced back to the USA's proclamation of independence in 1776 and the opening up of US harbors to foreign ships. This led to increasing levels of activity with the result that, in 1913, Hamburg was declared as the third biggest Harbor in the world after London and New York. But after WWII, due to bomb damage, almost nothing was left of Hamburg and the whole city was left in ruins. Soon after the war, the city was re-built once again ${ }^{[6]}$.

According to an interview held with Mr. Heinz Oberlach, HHLA press officer, the largest "Free Harbor" of the world is in Hamburg. According to HHLA, the main part of Hamburg Free Harbor was 
built during 1885-1910 due to Hamburg's participation into the German Costume Union in 1881.

As noted earlier, the HHLA has its offices inside the Free Harbor in an area called "Speicherstadt", "Warehouse City". HHLA has, in total, 359,000 square meters of available space, divided into 322,000 square meters warehouse facilities and 37,000 square meters office facilities. HHLA itself, uses only 31,000 square meters of the facilities and the rest is rented out to different tenants in different business lines.

The percentage of the distribution of the tenant's business lines and activities in HHLA's buildings are as follows: Offices for personnel and warehouse handling agents $70 \%$, Carpet trade $11 \%$, Shipping agents and related $10 \%$, Tea trade $1 \%$ and all other business lines including buildings without any tenants $8 \%^{[6]}$.

Looking closely at the structure of the Hamburg Free Harbor and the "Warehouse City", it appears that the harbor is divided into different sections, for example "Container" section or "Cool House" section and so forth. The same terminology is also used in the "Speicherstadt" (Warehouse City), such as Tea and Coffee section, Carpet section and so forth. It is in this area, "Speicherstadt", where carpet traders have their "Trading Houses". More specifically, the carpet trade is conducted from three different streets in the "Warehouse City":

- Brooktorkai

- Am Sandtorkai

- Magdeburger Strasse

By closely studying the carpet "Trading Houses" in these three streets, the concentration of Iranian Persian carpet trading houses can be seen in all three areas. These trading houses are mainly located in 6-storey high buildings and, normally, two different trading houses on each floor can be observed. Each trading house consists of approximately $300 \mathrm{~m}^{2}$ of warehouse and office space with approximately $3.5 \mathrm{~m}$ distance between the floor and ceiling.

All of the other handmade carpet producing nations such as P.R. of China, India, Pakistan, Afghanistan, Turkey and the other nations are, in contrast, located at only one street, namely, "Am Sandtorkai". Here, approximately 50 trading houses from the other carpet producing countries are situated in adjacent locations. According to interviews with the traders and HHLA, "Am Sandtorkai" is less attractive, buildings are not renovated, there are no customer elevators and, due to all theses disadvantages, HHLA demands less in rent. HHLA demand the highest level of rent from the tenants in "Magdeburger Strasse". These buildings are newer than the others and the level of rent reflects the condition of the buildings and range of facilities and is not an indication of the level of business activity. The oldest and the most attractive business area is "Brooktorkai" where the level of rents is in between the two other areas and, according to the HHLA, the most powerful and demanding tenants of these three areas have their trading houses located there. According to "Brooktorkai" traders, HHLA has always met their demands and wishes regarding buildings. One important demand, made several decades ago, was for the installation of customer elevators.

The combination of "Latecomers" and "Newcomers" (The expressions "latecomers" and "newcomers" refer, respectively, to Iranians who came to Hamburg Free Harbor before and after the 1979 revolution in Iran) can be found in all three areas. One particular change regarding the replacement of "latecomers" by "newcomers" is, according to the interview data, that a notable number of Iranian Jews who had their trading offices in all three areas of the carpet trade in Hamburg Free Harbor, sold their businesses and left Germany, mainly moving to the USA and Israel. Iranian Jews, in the main, sold their businesses to Iranians who left Iran after the revolution and these "newcomers" who took over the trading houses were largely of "Azari" descent with close ties to Tehran Carpet Bazaar. According to interviews (These interviews were telephone interviews with former Persian carpet traders in Hamburg of IranianJewish descent, who are currently resident in the USA. A brief summary of one of the interviews is as follows: "We could feel that the supply channels would become tougher and we probably could not return to Iran: at the same time, we even heard some gossip about export bans from Iran on carpets in general, which actually happened. That is one of the reasons why we actually decided to leave the business and sell it to some "newcomers" who can find their way around in Iran with the right supply channels. We came over her, to New York and established a new "Carpet Trade Centre" for ourselves. We had to admit that we could neither get "new" Persian carpets nor did we want to compete with Hamburg. That's why we established our own Persian carpet business in the USA based on "Antique" and "second-hand" Persian carpets. In doing this, we cut off our ties with the establishment in the Tehran Carpet Bazaar. While the situation got even worse for Persian Carpet traders both in Tehran and Hamburg, when the USA imposed an import ban on Iranian goods to the USA, we set up our organization in such a way that today we have the world's largest "Antique" trade of Persian carpets run by Jewish-Iranians in and around 
New York's 5th Avenue) held with three former Iranian-Jewish carpet traders in Hamburg Free Harbor, now residing in the USA, they could more or less "feel" certain tensions emanating from the suppliers' side and were, therefore, forced to think of alternatives, resulting in selling their businesses in Hamburg.

Almost all carpet trading nationalities in Hamburg Free Harbor and Iranians in particular, use their "cultural competency" and only deal with carpets from their own country of origin. Because of this, products and trading houses are segregated by owner national origin.

The photograph below (Fig. 4) shows a map of the three different areas (encircled) of the carpet trade in Hamburg Free Harbor, "Speicherstadt". The biggest area (see left of map) is where "AM Sandtorkai" is located. This area has "Multi-National" carpet trading houses, with the most frequent traders originating from India, Pakistan, Afghanistan, China and Iran. Only a couple of carpet traders from Turkey are represented. In this area, there are approximately 60 trading houses, of which around 20 originate from Iran. The smallest encircled area (see lower right of map) is where "Magdeburger Strasse" is located. This area has "Mono-National" carpet trading houses, dealing only with Persian carpets. There are approximately 30 trading houses in this area, almost all of which are of Iranian origin with the exception of a couple of traders of German origin. The remaining area (see upper right of map) shows the location of "Brooktorkai". The area has "Mono-National" carpet trading houses and only deals in Persian carpets. In this area, there are approximately 180 trading houses, almost all of which are of Iranian origin with the exception of a couple of traders who are of German origin.

The in-depth analysis of the location of the Iranian Persian carpet trader indicates that Iranians are not distributed across three different areas due to the lack of space in one area, but rather due to their preferences and networking practices. Iranians in the "Am Sandtorkai" area are in most cases, ethnically classified as "Persians" and both "latecomers" and "newcomers" can be found. In a few cases some Iranian "newcomers" who are ethnically classified as "Azari" (Azarbaidjanian from Iranian Azarbaidjan province) origin can also be observed and, in even rarer cases, some "latecomers" of "Azari" origin. Iranians in "Magdeburger Strasse" mainly consist of "latecomers", almost all of whom are, ethnically "Persian": In a couple of cases, Iranian-Jewish traders and Azari traders can be observed. A few, ethnically, "Persian" "newcomers" have replaced the former Iranian-Jewish "latecomers". Almost all Iranians in "Brooktorkai" are, ethnically, "Azari", both "latecomers" and "newcomers". A few ethnically "Persian" and IranianJewish "latecomers" can be observed. Some of the "Azari" "newcomer" traders have replaced some of the Iranian-Jewish "latecomer" traders, who left Hamburg after the revolution in Iran and moved to USA or Israel.

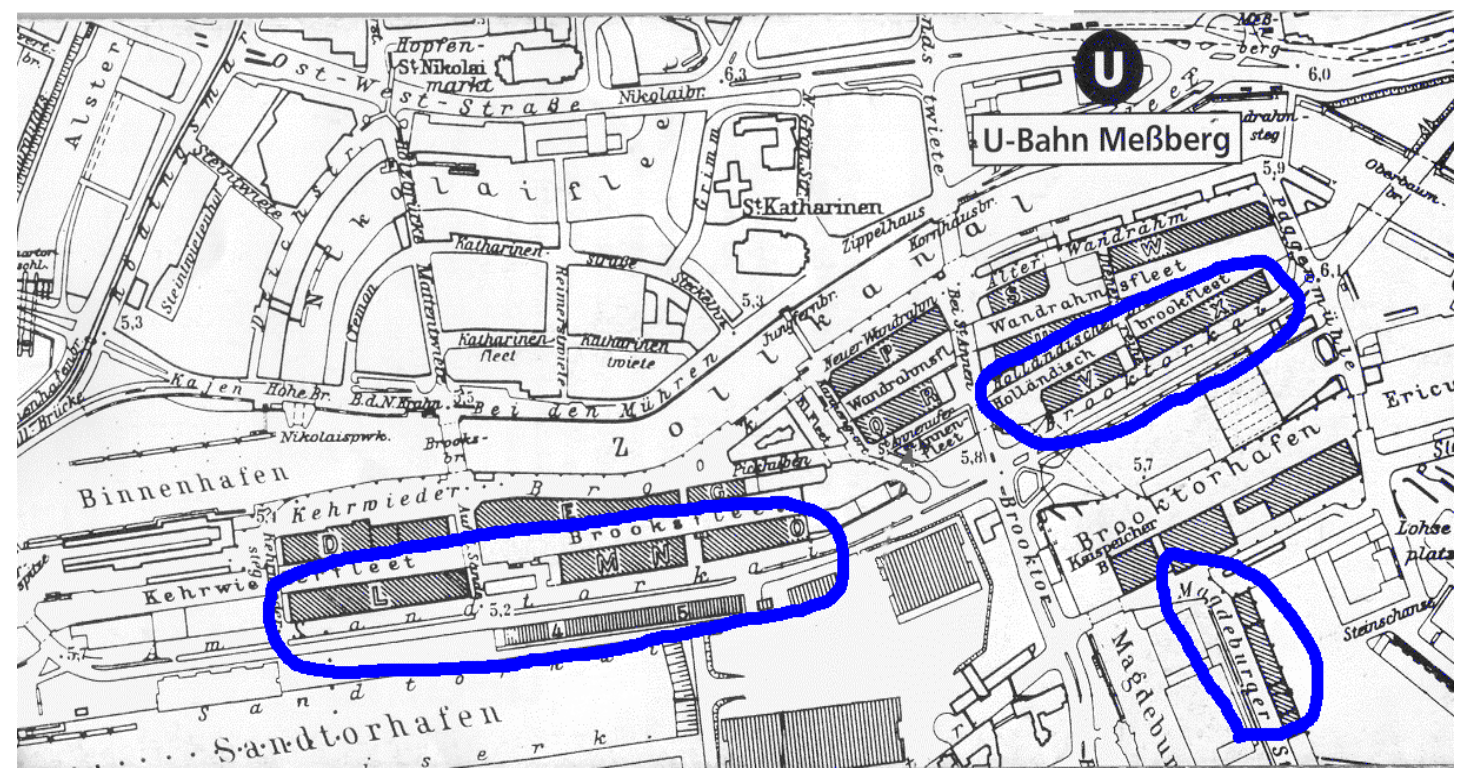

Fig. 4: Map of the three main carpet trade areas in Hamburg Free Harbor. Source: Speicherstadt Museum, presentation leaflet 
The segregation that exists amongst Iranians of different ethnic backgrounds is also apparent when looking at the interior design of the trading houses belonging to different ethnic groups. Almost all trading houses belonging to "Azari" traders can be divided into four distinct sections: (1) Entrance to a large and empty hall. The hall is kept clear for receiving and dispatching carpets: in an annex to the entrance hall, one usually finds a small kitchen (2) A waiting room for guests/customers where it is also used as an office for the manager of the trading house (3) An office behind or beside the waiting room belonging to the owner of the trading house, which is completely separate from the manager's office (4) Linked to the large and empty entrance hall is the warehouse: the warehouse is behind a thick steel fireproof door, which is almost always closed to strangers so that no uninvited person can gain admittance to the carpet warehouse and inspect the carpets inside.

Almost all trading houses belonging to "Persian" traders can also be divided into four distinct sections but with a much different internal layout to that of the "Azari" traders. The interior design of "Persian" trading houses usually takes the following form: (1) Entrance to a large hall where the carpet warehouse begins: the same area is used for receiving and dispatching carpets (2) At the end of the warehouse hall, or along the hall, a waiting room for guests/customers is prepared. The room is designed in such a way that guests/customers can look into the warehouse through windows and inspect the carpets: this room is also used as the manager's office (3) Linked to the manager's office is another office, which belongs to the owner of the trading house. This room is completely separate from the manager's office (4) A small kitchen can be found at the end of the warehouse hall or along the hall.

In spite of the clear ethnical segregation and strong competition against each other amongst Persian carpet traders in Hamburg Free Harbor, this limited group of traders stick together against the "outsiders" in order to remain in control of their world-wide multi billion dollars trade.

The above photograph (Fig. 5) shows over 30 members of the only official Association of the Iranian Carpet Importers in the Hamburg Free Harbor "Verband Iranischer Teppichimporteure" (VIT). According to "Persian Carpet" ${ }^{\text {"20] }}$ the picture above is taken in connection with a VIT meeting held on July 13, 1994. A number of members were absent due to "summer vacation". The subject of the VIT meeting, according to "Persian Carpet" was the new regulations regarding the export of carpets from Iran, imposed by the Iranian Government and the Iranian Central Bank.

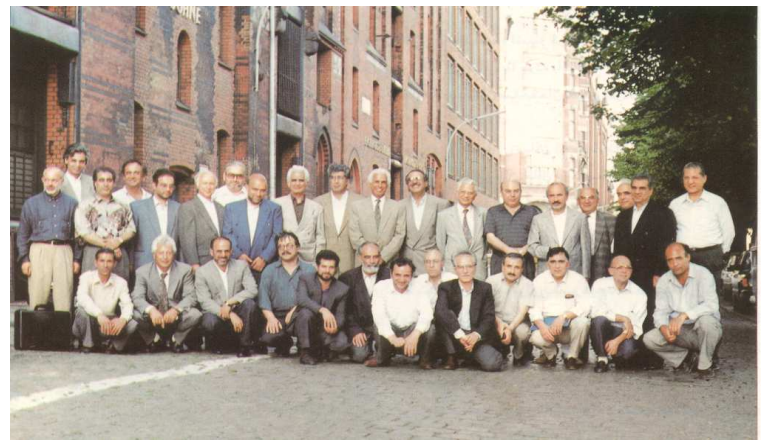

Fig. 5: A selected number of the members of the Association of the Iranian Carpet Importers in the Hamburg Free Harbor. Source ${ }^{[20,21]}$

According to "Persian Carpet" ${ }^{[20,21]}$ during a 31/2 h long discussion, VIT members rejected the new regulations and prepared a set of alternative propositions to the Iranian Central Bank and the Iranian Government; not surprisingly, the propositions are quite different to those imposed by the Iranian Authorities and their potential impact is examined in "Persian Carpet"[20,21].

According to the interviews with the traders in Hamburg Free Harbor, the "normal" way of negotiation with the Iranian Trade Authorities, both in Hamburg via diplomatic channels and directly in Iran, is to show "who" is behind the "Propositions" and then start the negotiations with the hope of being able to shape the new regulations in a more flexible way. In an interview Mr. Habib Mashreghzamini (shown sitting third from the right in the picture above) former Chairman of VIT and one of the leading figures in Hamburg Free Harbor said, "we can only hope to be able to influence the Iranian authorities' regulations by proposing our (VIT's) common requests through our networking and public channels like VIT's "Persian Carpet Journal" which we also forward to the authorities".

The importance of the Persian carpet trade to Iran is indisputable. This is also confirmed in a speech given by the former Iranian Minister of Trade, Mr. A. Vahadji, during his visit to Germany in December 1992. According to "Persian Carpet" ${ }^{\text {[19] }}$ the Minister was invited to a meeting arranged by the members of VIT in Hamburg to discuss several different export obstacles imposed by Iran regarding Persian carpets. The Minister is quoted as saying: "We are trying to ease transportation problems for you: one issue to mention is establishing special "Carpet Export Terminals" at Tehran airport: another easing of restrictions to come is the plan to establish a direct cargo line between Tehran and Hamburg, adding to the existing passenger carrier line, ${ }^{,[19]}$. 
At the same meeting the Minister is also quoted as saying, "At this stage we have production of carpets in 30,000 of our villages and more than 1 million workshops are set up and more than 8 million people in Iran are directly or indirectly involved in the carpet industry. Iran's export of carpets during last year (1992) was, in weight, only $1 \%$ of the total of Iranian non-oil exports, but the monetary value of that $1 \%$ was more than $35 \%$ of the total of Iran's non-oil exports" ${ }^{\text {"[19] }}$. The official estimated value of the annual export of carpets from Iran is approximately between USD 1.5-2 billion. (There is not "only one" reliable and standard way of declaration in different countries' customs. Some statistics are based on the monetary value of carpets. Others measure in square meters and value per square meter. Yet others measure value weight. Eurostat, as presented here, measures "Hand-knotted and Handwoven carpets" on the basis weight and monetary value. A final problem is an "Underestimation" of the real value, when dealing with any type of merchandise that is subject to duty and then using Customs documents as official statistics).

Taking an in-depth look into the case, the evidence shows that the "single entity" image of traders in the Free Harbor as presented to the outside world consists, in reality, of a series of ethnically defined sub-groups that each occupy different positions in the internal hierarchy. The fact is that Persian carpet traders of "Persian ethnicity" are a minority group and are forced to play the game and follow the agenda set by the majority group. According to interviews with Persian carpet traders of Persian descent in "Am Sandtorkai" and "Magdeburger Strasse" the business agenda is set by the "Azari" traders in "Brooktorkai" and their respective trading partners in Tehran Carpet Bazaar.

Much of the Hamburg-Tehran business constellation is built on an affinity between family members and strong ties based on trust. In some rare cases these affinity relationships are replaced by longterm historical business relationships built on mutual trust. According to interviews with the traders of Persian descent in Hamburg Free Harbor, only when "non-Azari" traders learn to speak "Azari" language, can they become trustworthy and equal business partners, able to participate as one of the "Price Setters" and no longer restricted to the role of an ordinary "Price Taker" agent.

A wide range of evidence indicates that certain values and norms, other than those of business flair and rationality, play a significant role. Amongst the traders in Hamburg Free Harbor the role of "Cultural Competency" and "Multi-linguistical" abilities are of much more importance than "Financial Capacity". This was evidenced when, after the Iranian revolution in 1979 and subsequent nationalization of almost all Iranian industries of importance to the country as well as imposing import and export restrictions, the Iranian Government established a number of trading "Funds" with the authority to control all foreign trade. These funds established a number of trading offices outside of Iran and were in charge of selling Iranian merchandize on the one hand and purchasing foreign merchandize to send off to Iran on the other hand. Due to historical reasons Germany, particularly Hamburg, became one of the main countries to set up these kinds of new offices as well as the United Arab Emirates, with Dubai in particular, due to its short distance from Iran, becoming another centre for these new offices. In the first few years after the Iranian revolution private traders were not allowed to export carpets outside Iran. The existing of Iranian Governmental and Semi-Governmental trading offices made Dubai into a new "Persian Carpet" trade centre. At the same time, the decrease in the number of Persian carpets on the world market pushed the demand and prices to a high level. Consequently, a traffic of smuggling carpets out of Iran into Dubai was inevitable. Another negative side of these market fluctuations was that some other "Hand-knotted carpet producing" countries like India, Pakistan, Afghanistan, Turkey and China tried to take over the market and, to a certain degree, even to copy Persian carpet designs in order to make a lucrative business. At this stage the Hamburg Free Harbor Persian carpet traders were fighting on many different fronts. The major problems were: (1) Export restrictions from Iran (2) Losing market share to Dubai (3) Competing with the new established Governmental trade offices both in Germany and elsewhere (4) Losing market share to all the other Hand-knotted carpet producing countries and 5. Barter-trade bilateral and multi-lateral agreements between Iranian Governmental bodies and foreign countries.

According to the interviews with the Iranian Persian carpet traders in Hamburg Free Harbor the most important reason that the Iranian Persian carpet traders of Dubai were not able to take over the business from Hamburg, although they played an important role during the first 2-3 years after the revolution in Iran, was firstly due to "lack of historical business records" engendering feelings of natural "distrust" in the established network of Tehran Carpet Bazaar traders, shown in the way traders in Tehran Carpet Bazaar would only deal with them in cash. The second reason was again due to "lack of historical business records" amongst world-wide buyers, in the way that buyers were only willing to purchase in small numbers and that 
was again due to "distrust" and "uncertainty" regarding after sale service. Consequently, after grasping the fact that other Hand-knotted carpet producing countries were taking advantage of the situation in Iran and realizing the importance of the carpet industry in Iran, the Iranian government eased the export ban on Persian carpets and lifted some of the restrictions. Iranian traders in Hamburg, by using their channels of distribution in Iran, were soon back in business in Hamburg.

At this stage, the mid 1980s, a number of Governmental and Semi-Governmental trading offices were established in Hamburg Free-Harbor, mainly in the "Am Sandtorkai" area. According to the interview data, "the policy of these offices was to sell off as many carpets as possible, side by side with "private" traders, at almost "give-away" prices. According to the interviewees "in spite of these offices unlimited access to carpet workshops across the country and sufficient capital to purchase carpets for cash in Iran, all these offices were, one by one, forced to shut down, due to buyers' "distrust" of them and "lack of business records". The last Governmental trading house in Hamburg Free Harbor was the "Iranian Carpet Company", as mentioned earlier, the largest carpet producing entity in Iran and under direct administration of the Iranian Ministry of Trade. But even this Governmental trading house was recently forced to close down. As an alternative solution and in order to continue with some level of activity, the "Iranian Carpet Company" has left the "Hamburg Free Harbor" area and moved to a recently built "exclusive" shopping centre area, called "Borsteler Chausee" inside Hamburg City, around Hamburg Airport and has given up the advantages of being in a "Free Harbor" area and acting as wholesaler. It now operates using the slogan: "Direct sale from Producers to Customers".

One of the other huge obstacles facing Persian carpet traders in Hamburg Free Harbor was, according to the interviews, "being held as hostages in some political dispute between Iran and the USA". Due to political tensions, the USA imposed economic sanctions on Iran and its products. As a result the Persian carpet traders in Hamburg Free Harbor lost one of their most important markets. Having endured several years of losing their market share to other hand-knotted carpet producing countries and experienced a difficult period of time due to the political situation, the Iranian Persian carpet traders in Hamburg Free Harbor may once again be able to look to the future with optimism.

\section{CONCLUSION}

The statistical data on the hand-knotted carpet trade for the period 1976-1989 confirms the role of Hamburg as the world's leading trading centre of hand-knotted carpets. The same data also indicates different fluctuations of the hand-knotted carpet trade. These fluctuations can be historically explained, especially in connection with the aftermath of major political turbulence in Iran since 1979, the spreading of state controlled trading companies inside and outside of Iran and increasing international market pressure due to the growth in the practice of copying traditional Persian carpet designs in other countries. Despite this, the Teheran-Hamburg axis remains the core in this tradewith private "Azari" speaking Iranian traders in the dominant position on both sides of the transaction line.

The historical evidence presented here illustrates the formation of one of the strongest single-commodity trade centers of the world controlled by a couple of hundred businessmen and shows how a limited group of traders in Hamburg Free Harbor stick together in order to remain in control of this multi billion dollars trade while, on the other hand, competing strongly amongst themselves in their private businesses. Furthermore, the evidence also illustrates that the Iranian carpet traders, both in Tehran and in Hamburg Free Harbor, consist of different ethnic backgrounds and the Iranian "Azari" traders is the group controlling the carpet market. Evidence also showed the existence of a hierarchy of subethnic groups from the same country and a pattern of overlapping ethnic identities, which challenge the mainstream "ethnic business" theory.

The evidence illustrates how Persian carpet traders from Iran in Hamburg Free Harbor have survived different crises as a world war, political turbulence, cuts and shortages in supply and financially strong "new actors" in the Persian carpet trade could not break down the existence of strong ties and networks which had been built up during decades and even centuries. Furthermore, all the financially powerful actors were, one by one, forced to leave this line of trade due to the lack of sufficient networks. Historical evidence also illustrates the strongest kind of relationship is affinity relationships between families.

The theoretical perspectives introduced in chapter 3 as the point of reference and the arena for future theoretical articulation and conceptualization are in the following confronted with the empirical findings of the study. Dealing with ethnic economy /immigrant business involves at least three aspects: Forms of globalization; Concept of ethnic business and the shaping of business relations.

In accordance with the insight of economic sociology of immigrant businesses (mentioned in chapter 3) this study shows: That the Global Persian Carpet Trade started as small family units and through out the decades evolved 
into a huge industry. That is not, however, the case for the majority of immigrant businesses, many remain small and many others close down. The crucial questions are firstly why and how it happed and secondly what implication the empirical case might have for our understanding of immigrant business/ethnic economy or ethnic enclave economy:

- One of the very specific features of The Global Carpet Trade, as it has been shown here, is it's international orientation at the very early stage of development, connecting the long tradition of production in the country of origin to the neighbor country

- The other one is the articulated and elaborated sensitiveness and response-readiness and capability of the founders of the business to changing political and institutional environment. Surprisingly, taking into account the established conceptualizations of ${ }^{[4,17,27]}$, immigrant business, the case of Global Persian Carpet Trade surprisingly indicates clearly almost no corporation with similar industries in other countries beyond qualifying and taking advantage of the production infrastructure in the country of origin and linking domestic producers to foreign consumers

- The study also shows that the controlling carpet business elite has managed to keep it's privileged position by not allowing entrance to others than insiders and institutionalizing the terms of entrance

- As it was highlighted in chapter 3 the internationalization processes are usually understood as large firm driven, with large firms becoming international or global more quickly and more extensively than SMEs and with SMEs often being understood only as sub-suppliers to the large, international units and hence as reactive rather than proactive. The case of The Global Carpet Trade indicates clearly the longitude strategic behavior that make SME's to become the largest actor on the global scenes for a specific product. Much knowledge is to be revealed with regard to the question of whether it is intellectual articulation or muddling through (learning by doing) that make the difference between survivors and those who surrender for the pressure

- The case therefore challenges the inherent largefirm bias in this standard conceptualization with regard to internationalizations. Incidents to be clarified empirically include further whether the SMEs horizontal corporation (as suggested by the established conceptualizations, see chapter 3) in practice play a role and in that case what conditions must be in place before such an option is strategically preferred

- The case also challenges the importance of international networks being in place prior to internationalization of the specific industry, or it should be created/activated for succeeding in border crossing businesses

- However, the case of The Global Carpet Trade reveals much support for the idea of trading diasporas sharing features, such as strong ethnic identity and mutual dependence, informal networks based on mutual trust and family reputation and a belief in the utility of knowledge from all possible sources $^{[11]}$. The case, on the other hand, brings about evidence that the scope of ethnic group relevant for business success probably should be limited to those of very close relatives, not including the whole ethnic group. In other words it might not be belonging to the ethnic group in general, however it is defined, but qualifying as individuals by merits and records of trustworthiness for the membership of the relevant inner circle that counts. This might be the very dynamics of the bottom up process. On the other hand the inner circle might include individuals who are not by birth included in the constructed ethnic community, but who through a long process qualify for being subject to the trust of the inner circle

Turning back to the second set of theoretical prospective of relevance to this study, that of the very concept of ethnicity or of "ethnic groups" the presented case here contributes to the understanding of what "Ethnic" means in ethnic businesses. Not only separate (sub) ethnic business networks, such as those found by Light in his study of Iranians in Los Angeles ${ }^{[14]}$, but also a hierarchy of (sub) ethnic groups from the same country and a pattern of overlapping ethnic identities. The case reveals the theoretical and empirical need for another further/deeper move beyond boundaries of ethnicity and into the core cluster of individuals or controlling elite, the inner circle, entrance in which requires the broader ethnic solidarity only as a minimum of requirements. Even stronger ties will be required.

A third theoretical topic of relevance for the study described in chapter 3 was that of strong ties, weak ties, "the network advantage" and "the cultural competence advantage". Usually, therefore, immigrant businesses are strong in city areas where many immigrants live and in sectors, which deal with culture-loaded goods and services. The case of The Global Carpet Trade shows 
strong evidence for this. The question; however, is whether concentration in specific economic sectors by it self can safeguard the privileged position without assistance from other not directly inner circles and network, which belong to the same ethnic community. There is now empirical indication for cross-network activities and the possible role they can play.

Finally going back to the theoretical insight on the dark side of ethnically closure of the inner circles, that limits the flow of information from outside (that must only be the case where parallel business circles of the same ethnic community are not existing ${ }^{[3,8]}$, the case of The Global Carpet Trade shows so far no indication. The major hurdle for the business and the rolling business elite has not obviously not been the result of lack of information, but of the political and institutional character imposed by the government. As far as the impact of information flow is concerned the case indicates a need for future conceptualization and operationalization of ethnic enclave economies that along side many features among which the type of product, the type of infrastructure, the type of consumer, network and the impact of parallel inner circles of the same ethnic community should be emphasized.

\section{ACKNOWLEDGMENT}

I owe a deep debt of gratitude to the LOK program (a research program initiated by the Danish Government to develop new knowledge to support in their work with management and organizational changes) for their generous financial support, for the first draft of this study, during my time in Hamburg and especially to Professor Torben Bager, University of Southern Denmark, Institute of Organization and Management and Professor Bent Greve, Roskilde University, Department of Society and Globalisation, for their professional guidance and to all interviewees without whom this publication would not have been possible. Thanks also go to Professor Thomas Straubhaar, Dr. Hubertus Hille and Malgorzata Stankiewicz, University of Federal Armed Forces, Institute for Economic Policy Research (Universität der Bundeswehr)-Hamburg, for letting me use their facilities during my time in Hamburg. Thanks are also extended to Karen Gausland and Bjørn Birkely Nielsen, the Danish Department of Customs and Tax for forwarding special extraction of statistical data and to research assistant, Svend Møballe for his comments and guidance in computing the statistical data at Roskilde University, Denmark).

Thanks is also extended to non-anonymous interviewees, whom are listed here:
In Germany: Mr. R. Albrecht, Mr. R. Amirkhizi, Mr. H. Arzanesch, Mr. R. Arzanesch, Mr. S. Azadi, Mr. S. Davood, Mr. A. Hosseindjani, Mr. G. Kermanshahi, Mr. H. Mashreghzamini, Mr. Milani, Mr. P. Möller, Mr. Nikandish, Mr. H. Oberlach, Mr. M. Saghafi, Mr. Shaker, Mr. H. Shayesteh, Mr. K. ZarinKafsh,

In Denmark: Mr. R. Rejaye and In the Netherlands: Mr. H. Heydarpour and Mr. E. Spruit.

\section{REFERENCES}

1. Aldrich, H. and C. Zimmer, 1987. Resource mobilization through ethnic networks: Kinship and Friendship Ties of Shopkeepers in England. Sociologic. Perspect. 30: 422-445. http://www.jstor.org/pss/1389212

2. Aldrich, H., C. Zimmmer and D. McEvoy, 1989. Continuities in the study of ecological succession: Asian businesses in three English cities. Soc. Forces, 67: 920-944. http://www.jstor.org/pss/2579708

3. Burt, R.S., 1992. The Social Structure of Competition. In: Networks and organizations: Structure, form and Action, Nohria, N. and R.G. Eccles (Eds.). Harvard, Boston, ISBN: 0071033742.

4. Chan, K.B., 1992. Ethnic resources, opportunity structure and coping strategies: Chinese business in Canada. Rev. Européenne des Migrations Int., 8: 117-137. http://www.informaworld.com/smpp/content conten $\mathrm{t}=\mathrm{a} 732618280 \sim \mathrm{db}=$ all $\sim$ jumptype $=\mathrm{rss}$

5. Dimaggio, P. and W.W. Powell, 1991. The New Institutionalism in Organizational Analysis. Chicago University Press, Chicago, ISBN: 0226677087, pp: 478.

6. Farsh Iran, 1994. The official publication of the Association of the Iranian Carpet Traders, Verband Iranischer Teppichhandels, Hamburg (VIT).

7. Geertz, C., 1963. Old Societies and New States. The Free Press, New York.

8. Granovetter, M., 1973. The Strength of Weak Ties. Am. J. Sociol., 78: 1360-1380. http://www.jstor.org/pss/2776392

9. Granovetter, M. and R. Swedberg, 1991. The Sociology of Economic Life. Westview, Boulder, ISBN: 0745001513, pp: 224.

10. Iyer, R.G. and J.M. Sharipo, 1999. Ethnic entrepreneurial and marketing systems: Implications for the global economy. J. Int. Market., 7: 83-110. http://www.jstor.org/stable/25048787

11. Kotkin, J., 1994. Tribes: How Race, Religion and Identity Determine Success in the Global Economy. Random House, New York, ISBN: 0679752994, pp: 343. 
12. Li, P.L., 1993. Chinese investment and business in Canada: Ethnic entrepreneurship reconsidered. Pacific Affairs, 66: 219-243. http://www.jstor.org/stable/2759368

13. Light, I., 1972. Ethnic Enterprise in America. University of California Press, Berkeley, ISBN: 0520017382, pp: 461.

14. Light, I., Bozorgmehr, M. and C. Der-Martirosian, 1991. The four Iranian Ethnic Economics in Los Angeles. Proceeding of the Paper Presented at the Annual Meeting of The American Sociological Association, Cincinnati, Aug. 23-27.

15. Light, I. and C. Rosenstein, 1995. Race, ethnicity and entrepreneurship in urban America. De Gruyter, New York, ISBN: 0202305066, pp: 255.

16. Light, I. and S.J. Gold, 2000. Ethnic Economies. Academic Press, California, ISBN: 0122871553, pp: 302.

17. Ong, P., E. Bonacich and L. Cheng, 1994. The new Asian Immigration in Los Angeles and Global Restructuring. Temple University Press, Philadelphia, ISBN: 1566392187, pp: 330.

18. Perrow, W., 1993. Small-Firm Networks. In: Networks and Organizations: Structure, form and Action, Nohria, N. and R.G. Eccles. (Eds.). Harvard, Boston, ISBN 0071033742.

19. Persian Carpet, 1993. The official publication of the Association of the Iranian Carpet Importers. Verband Iranischer Teppichimporteure, Hamburg (VIT).
20. Persian Carpet, 1994. The official publication of the Association of the Iranian Carpet Importers, Verband Iranischer Teppichimporteure, Hamburg (V.I.T.).

21. Persian Carpet, 1995. The official publication of the Association of the Iranian Carpet Importers, Verband Iranischer Teppichimporteure, Hamburg (VIT).

22. Portes, A., 1995. The Economic Sociology of Immigration. Russell Sage Foundation, New York.

23. Redding, S. Gordon, 1990. The Spirit of Chinese Capitalism. Walter de Gruyter, New York.

24. Smelser, N.J. and R. Swedberg. 1994. The Handbook of Economic Sociology. Russell Sage Foundation, New York.

25. Waldinger, R., H. Aldrich and R. Ward, 1990. Ethnic Entreprenzurs: Immigrant business in Industrialized Societies. Sage, London.

26. Weber, M., 1968. Economy and Society. In: Roth, G. and C. Wittich (Eds.). University of California Press, (1978 reissue), Bekerly and Los Angeles, CA.

27. Yeung, H.W.C. and K. Olds, 1999. The Globalization of Chinese Business Firms. MacMillan, London.

28. Yinger, J.M., 1985. Ethnicity. Ann. Rev. Sociol., pp: 151-180. 